\title{
A Systematic Review of Research: A Second Generation Instructional Design Lens on Physics, Autonomy Support, Gender Gap Reduction, and Measuring Mathematics Reasoning Ability
}

\author{
Jeffrey C. Lear \\ East Stroudsburg University of PA, United States
}

\begin{abstract}
Physics and mathematics learning outcomes have specific cognitive development implications. Can details emergent from cross-disciplinary investigation assist teachers in meeting inclusive education goals? Some empirical studies in the learning of physics have focused on gender gap reduction using interactive engagement (IE) learning environments. Other studies in the learning of mathematics have focused on 'thinking mathematically', particularly investigating student interpretations of symbols and expressions. A third group of studies examine IE classroom settings to better understand subject specific autonomy supportive interventions designed to engage the intrinsic motivation within students. This configurative systematic literature review synthesizes manuscripts on (a) mathematics/physics cognitive development, (b) subject specific autonomy supportive behavior, and (c) physics learning gender gap reduction. Is reasoning ability an important mediating factor in evaluating physics learning outcomes? This review has implications for researchers, supervisors, and teachers who are addressing subject specific instructional needs, or are continuing empirical research in physics learning. Supervisors of physics instructors need to have differentiated assessment instruments to negotiate responsibilities in clinical observation collaborative conferences. The purpose of this review is to bridge the pioneering work in mathematics and physics research; and inform concurrent investigations. It is recommended that future physics learning studies additionally measure mathematics reasoning ability using a concept inventory instrument designed to measure 'structure sense'.
\end{abstract}

\section{Introduction}

This meta narrative review of the literature will present current research paradigms in physics and mathematics learning [9]. This paper follows a blend of two forms known as explicit systematic review and thematic/argument review [9]. The author determined this blend as appropriate given the empirically derived conceptual models available, and the specificity of defined terms in the respective lines of inquiry. Included is an analysis of conventional research methodologies under three theoretical lenses. Current research in mathematics learning will be linked to improved reasoning abilities common to both disciplines [7]. As a result, new research questions can be posed to frame continued physics learning investigations inclusive of structure sense.

Mathematics reasoning skills have been shown to be factors in decisions to enroll in physics courses. Multiple studies investigating interactive engagement (IE) learning environments have shown that specific autonomy supportive instructional practices reduce gender gap performance in physics achievement [3], [5], [7], [18]. One investigation finds reasoning ability among specific populations is a significant indicator to success in physics classes where interactive engagement (IE) and autonomy support are present [5]. The longitudinal effect of underdeveloped reasoning skills may contribute to decreased performance in physics learning for certain populations [11].

\section{Objectives of the study}

An objective of this configurative review is to examine the extent of physics learning studies measurement of the mathematics cognitive development construct, sense making. Specific teaching methods are required for proper vertical and horizontal integration of science (and mathematics) subject matter content [8]. The most significant contribution of this review is its potential to be a foundation for concurrent discussions on:

1. improved pedagogical techniques addressing cognitive development in sense making and thinking mathematically, 
2. gender gap reduction in the learning of physics and mathematics, and

3. autonomy supportive interventions common in IE subject specific instructional settings.

This type of concurrent instructional design examination is consistent with second generational design models (ID2). Instructional design models originating from the field of experimental learning philosophy have expanded to include developments from the field of cognitive psychology [19]. The objective of this study is timely in its examination of an interdisciplinary cognitive development construct, sense making.

This manuscript will detail mathematical spaces key for instructors assisting all learners in the construction of ID2 mental models [19]. A Euclidian Space may be viewed as a vector space with the usual metric (distance) explored in secondary physics and mathematics education [16]. This focus on mathematical conceptual understanding, a refinement of structure sense, herein termed metric sense; is hypothesized to be instrumental in building empirical knowledge in physics instruction and the assessment of learning outcomes.

\section{Purpose and guiding question}

The purpose of this review is to clarify the need [4], [5], [11], [15] regarding concurrent research activity significantly impacting future knowledge production in physics and mathematics learning. Additionally, this review may inform researchers seeking refinement of specific instructional design models for increased student performance outcomes [8]. A thematic focus for this review is necessary since cognitive development, interactive engagement, and gender gap reduction are each imperative considerations for improved pedagogical subject specific instruction [8], [15], [19]. The following question guides the review. What pedagogical behavior must be considered in future investigations:

1. analyzing subject specific teacher autonomy support in a classroom experience,

2. exploring gender gap reduction in the learning of physics, and

3. measuring mathematical thinking.

\section{Subject specific thematic focus}

A framework was needed which depicts subject dependent individual learning processes. A framework was found in the "model for the analysis of student performance" [8]. The model incorporates the dimensions of classroom interaction, teacher expertise, cognitive abilities, and motivational behaviors. The model allows for a distinction between surface level and deep structure planning and instruction. This review seeks a cross-curricular view of current research in deep learning strategies though sense making cognitive development [8], [15], [25]. Schoenfeld [25] finds that without skilled instruction involving proper deep learning strategies, counterproductive conceptualizations can occur [14], [23]. Three compatible conceptual foci for the review's guiding question are now presented.

\subsection{Review conceptual focus: Autonomy Supportive Interventions (ASI) within Instructional Engagement (IE) settings}

A framework must allow for the exploration of relationships between teacher and student, focusing on the student motivation aspect of pupil developmental and academic achievement. An understanding of student cognitive and social development is essential to understanding student motivation. Abandoning impersonal relationships between teacher and student, which facilitate basic psychological developmental needs of the student, will negatively affect the learning experience and reduce academic success. Self-Determination Theory was chosen with a conceptual framework based on stages of human development [24]. Ryan and Deci [24] have identified a taxonomy of human behavior utilizing a continuum of motivation from impersonal through internal. Dimensions of the human motivation conceptual model consist of amotivation, extrinsic motivation, and intrinsic motivation. Intrinsic motivation increases academic success, while meeting a student's basic psychological needs.

It is conducive to this review to utilize an autonomy supportive conceptual framework, useful within classroom environments, which increase conceptual understanding of specific subject matter toward better academic performance [24]. The dialectic approach within self-determination theory suits this purpose and is an inclusionary criterion for the review. Conceptual understanding building in physics and mathematics entails a combination of; (a) specialized content specific instruction [4], [8], (b) student voluntary exposure to challenging tasks, and (c) deep involvement in subject matter [27].

\subsection{Review conceptual focus: Gender gap reduction in physics learning outcomes}

The Global Gender Gap Index provides an appropriate lens for depicting instructional elements 
pursuant of gender gap reduction in physics learning. The index measures the four key areas of health, education, economics and politics [10]. These areas are consistent with the dimensions of the chosen thematic model investigating science specific learning performance. Of particular importance to this review's inclusionary criteria are the conceptual impedances to the disparity in the subindex "educational attainment" [10]. Having a lens appropriate for including articles on gender gap reduction, attention is now turned to a conceptual framework for selecting manuscripts specific to thinking mathematically.

\subsection{Review conceptual focus: Cognitive development in sense making and thinking mathematically}

A COACTIV study provides a conceptual framework operationally defining mathematics teacher competence and effective instruction [4]. Two dimensions of this conceptual framework are specific to cognitive development and compatible to the thematic focus of the review [4], [8]. The facet of knowledge constructs of the pedagogical knowledge domain, specifically "knowledge about representing and explaining mathematics", captures the hidden mediating variable exemplified by this review [4]. The construct knowledge of students' mathematical thinking is also representative of explored mediating variables. The motivational orientations operational definition of subject specific behavioral tendencies, additionally supports selecting the framework pursuant the review's guiding question [4]. The COACTIV model is consistent with detailing dimensions of domain knowledge pertinent to making instructional decisions [19]. Having described compatible conceptual foci (lenses) supporting an overarching thematic focus, attention is now turned to the remaining aspects of this systematic review inquiry.

\subsection{Harmony among the thematic framework, conceptual model, and ID2}

A close examination of the COACTIV mathematics conceptual framework [4], the model for the analysis of student science learning [8], and ID2 instructional design theory modeling [8], [19] reveal a harmony in the importance of subject specific instruction. Drawing from independent research fields, each of the framework constructs converge on parallel concepts spanning education, experimental learning philosophy, and cognitive psychology (see Table 1). The author feels this underscores the timeliness and significance of this configurative thematic review [9].

Table 1. Construct Summary: COACTIV framework, Student Performance Conceptual Model, ID2

\begin{tabular}{|c|c|c|c|c|}
\hline Author(s) & Model & Year & Journal & Construct Relationships / Dimensions \\
\hline $\begin{array}{l}\text { Baumert, Kunter, Blum, } \\
\text { Brunner, Voss, Jordan, } \\
\text { Klosmann, Krauss, } \\
\text { Neubrand, \& Tsai [4] }\end{array}$ & COACTIV & 2010 & $A E R J$ & $\begin{array}{l}\text { * teachers' (a) deep understanding of } \\
\text { mathematical knowledge, (b) use of } \\
\text { mathematics-specific instructional strategies, } \\
\text { (c) considerations of students' cognitive } \\
\text { learning processes }\end{array}$ \\
\hline $\begin{array}{l}\text { Fischer, Klemm, } \\
\text { Leutner, Sumfleth, } \\
\text { Tiemann, \& Wirth [8] }\end{array}$ & MASP & 2005 & JSTE & $\begin{array}{l}\text { * teaching profession (school, classroom, and } \\
\text { subject context), social and cultural capital, } \\
\text { individual learning processes (cognitive, } \\
\text { motivational, social) }\end{array}$ \\
\hline $\begin{array}{l}\text { Merrill, Li, \& Jones } \\
\text { [19] }\end{array}$ & ID2 & 1990 & $E T$ & $\begin{array}{l}\text { analyzing and representing knowledge, } \\
\text { instructional strategies and transactions, } \\
\text { integration of ID phases (student cognitive } \\
\text { model components) facilitated by mini- } \\
\text { experts (teachers) }\end{array}$ \\
\hline
\end{tabular}

Note. * Adapted from graphical representations; AERJ = American Educational Research Journal; ET = Educational Technology; JSTE = Journal of Science Teacher Education; COACTIV = Cognitively Activating Instruction; MASP = Model for the Analysis of Student Performance; ID2 = Second Generation Instructional Design

Merrill, Li, and Jones [19] find elaborated cognitive structures are specific to the context by which learners analyze and represent knowledge. Intelligent mini-experts design instructional 
transactions to model deep structures in mathematics and physics domain knowledge bases [4], [8], [19], [25]. These instructional episodes differentiate interactions with students. The relationship between teacher and individual student must be formatively evaluated to social context as well the individual student external cognitive representations and internal processing of content [4], [8], [13], [24]. Advanced, content specific teaching skill is necessary for designing instruction customized to ID2 phases with differing deep structures and similar surfaces structures [4], [19], [24]. An advantage of ID2 modeling in instructional planning is a focus on an intentional integration of new information into the current state of students' knowledge bases [8]. This subject specific instructional design may assist teachers in meeting broader inclusive education goals at the institutional level.

\section{Review method sources}

Manuscript selection was drawn for their ability to synthesis empirical findings according to the aforementioned theoretical and conceptual frameworks. The blended methodology allowed the author to model the review after research structures while additionally performing extensive theoretical sampling [9]. Boolean searches were performed for each conceptual focus. A further refinement on the article selection process was determined by identification of construct inclusions of the remaining conceptual foci. The unique nature of this review posed difficulty formulating criteria for inclusion of articles reporting on pioneering research in their respective fields. To assist the researcher, the author utilized a criteria rubric specified in Figure 1. The rubric served in scoring article relevance to the review's guiding question. Additionally, the rubric scoring (see Table 5) allowed for broad descriptive interpretations of the state of current research in cross-disciplinary subject research.

\subsection{Sources for the review: Selection, data extraction, and coding for gender gap reduction}

A significant portion of the articles studying gender gap reduction in physics learning outcomes utilize a concept inventory instrument in an Interactive Engagement (IE) instructional setting. A limited quantity of research articles empirically testing physics outcomes required the author to carefully select articles pursuant to the thematic focus, yet also including aspects of motivation and cognitive skills analysis.

The gender gap research articles selected have findings from gender gap closure to significance in data revealing reverse gender gap conclusions (see Table 2). Articles with significant gender gap findings based on normalized gains in physics learning outcomes; prompted their inclusion in the review.

Table 2. Characteristics of research papers in physics achievement and/or physics gender gap reduction

\begin{tabular}{|c|c|c|c|c|c|c|c|c|}
\hline Author(s) & Year & Locus & Journal & $\begin{array}{l}\text { Conceptual } \\
\text { Focus }\end{array}$ & $\begin{array}{l}\text { Method of } \\
\text { Analysis }\end{array}$ & $\begin{array}{l}\text { Concept } \\
\text { Inventory }\end{array}$ & $\begin{array}{c}\text { IE } \\
\text { Design }\end{array}$ & $\begin{array}{c}\text { Gender } \\
\text { Gap/ } \\
\text { Normalize } \\
\text { Gain } \\
\end{array}$ \\
\hline $\begin{array}{l}\text { Coletta } \\
\text { and } \\
\text { Phillips } \\
{[5]}\end{array}$ & 2005 & $\begin{array}{l}\text { United } \\
\text { States }\end{array}$ & $A J P$ & $\begin{array}{l}\text { Reasoning } \\
\text { Cognitive } \\
\text { Develop }\end{array}$ & Correlation & $\begin{array}{c}\text { FCI, } \\
\text { Lawson }\end{array}$ & Yes & $\begin{array}{c}\text { Reasoning } \\
\text { Mediating } \\
\text { Variable }\end{array}$ \\
\hline $\begin{array}{l}\text { Lorenzo, } \\
\text { Crouch, } \\
\text { and Mazur } \\
{[18]}\end{array}$ & 2006 & $\begin{array}{l}\text { United } \\
\text { States }\end{array}$ & $A J P$ & $\begin{array}{l}\text { Gender } \\
\text { Disparity }\end{array}$ & t-test & FCI & Yes & Gap Closure \\
\hline $\begin{array}{l}\text { Kost, } \\
\text { Pollock, } \\
\text { and } \\
\text { Finkel- } \\
\text { stein [15] }\end{array}$ & 2009 & $\begin{array}{l}\text { United } \\
\text { States }\end{array}$ & $P R S T$ & $\begin{array}{l}\text { Gender } \\
\text { Disparity }\end{array}$ & $\begin{array}{l}\text { Regression } \\
\text { Modeling }\end{array}$ & FMCE & Yes & $\begin{array}{c}\text { Gender Gap } \\
\text { Mediating } \\
\text { Variable }\end{array}$ \\
\hline $\begin{array}{l}\text { Coletta, } \\
\text { Phillips, } \\
\text { and }\end{array}$ & 2012 & $\begin{array}{l}\text { United } \\
\text { States }\end{array}$ & $A I P$ & $\begin{array}{l}\text { Reasoning } \\
\text { Cognitive } \\
\text { Develop / }\end{array}$ & t-test & $\begin{array}{c}\text { FCI, } \\
\text { Lawson }\end{array}$ & Yes & $\begin{array}{l}\text { Mediating } \\
\text { Variable / } \\
\text { Reverse }\end{array}$ \\
\hline
\end{tabular}




\begin{tabular}{|c|c|c|c|c|c|c|c|c|}
\hline $\begin{array}{l}\text { Steinert } \\
{[7]}\end{array}$ & & & & $\begin{array}{l}\text { Gender } \\
\text { Disparity }\end{array}$ & & & & Gap \\
\hline $\begin{array}{l}\text { Adegoke } \\
\text { [3] }\end{array}$ & 2012 & Nigeria & $P E$ & $\begin{array}{l}\text { Gender } \\
\text { Disparity }\end{array}$ & $\begin{array}{l}\text { Quantitative } \\
\text { ANCOVA }\end{array}$ & $\begin{array}{l}\text { QPIG, } \\
\text { QPAT }\end{array}$ & Yes & Gap Closure \\
\hline $\begin{array}{l}\text { Hazari et } \\
\text { al. [11] }\end{array}$ & 2013 & $\begin{array}{l}\text { United } \\
\text { States }\end{array}$ & JCST & $\begin{array}{l}\text { Physics } \\
\text { Identity }\end{array}$ & Factor Analysis & $\begin{array}{l}\text { PRiSE } \\
\text { project } \\
\text { survey }\end{array}$ & No & $\begin{array}{l}\text { Mediating } \\
\text { Variable }\end{array}$ \\
\hline $\begin{array}{l}\text { Shi, He, } \\
\text { Wang, and } \\
\text { Huan [26] }\end{array}$ & 2015 & China & EJMSTE & $\begin{array}{l}\text { Gender } \\
\text { Disparity }\end{array}$ & t-test & USTL & No & Gap Closure \\
\hline \multicolumn{9}{|c|}{$\begin{array}{l}\text { Note. PE = Physics Education; AJP = American Journal of Physics; PRST = Physical Review Special Topics-Physics } \\
\text { Education Research; JRST = Journal of Research in Science Teaching; AIP = American Institute of Physics; EJMSTE = } \\
\text { Eurasia Journal of Mathematics, Science \& Technology Education; FCI = Force Concept Inventory; FMCE = Force and } \\
\text { Motion Concept Evaluation; Lawson = Lawson Classroom Test of Scientific Reasoning; PRiSE = Persistence Research in } \\
\text { Science and Engineering; USTL = University of Science and Technology Liaoning Laboratory Quiz; QPIG = Quantum } \\
\text { Physics Instructional Guide; QPAT = Quantum Physics Achievement Test }\end{array}$} \\
\hline
\end{tabular}

The seven gender gap studies identified were coded to nodes conventionally characteristic of Newtonian physics content. The Force Concept Inventory (FCI) instrument was found beneficial to the field studying physics outcomes [5], [7], [18]. Data was also extracted and coded to emergent nodes descriptive of methodological choices in investigating physics learning performance.

Instructional behavior found in gender gap studies focus on methods of instruction within interactive engagement (IE) settings (see Table 5) [3], [5], [7], [15], [18]. Data was extracted from gender studies and coded to nodes descriptive of motivational controls. Where motivational controls were found in gender studies, data was coded according to constructs of the dialectic conceptual framework [13], [25].

\subsection{Sources for the review: Selection, data extraction, and coding for intrinsic motivation}

Articles searched and selected along the focus of autonomy-supportive instruction (ASI), indirectly support, but conventionally do not directly specify (IE) instructional settings utilized in physics concept inventory experiments [2], [27]. There are limited quantities of research articles with a high focus on motivation and concurrently testing physics and mathematics performance under the aforementioned thematic focus (see Table 5). This restraint required this review to rigorously select articles pursuant the thematic focus, yet also include aspects of cognitive skills analysis.

Table 3. Characteristics of research papers on autonomy supportive interventions within IE

\begin{tabular}{lccccccc}
\hline Author(s) & Year & Locus & Journal & $\begin{array}{c}\text { Conceptual } \\
\text { Focus }\end{array}$ & $\begin{array}{c}\text { Method of } \\
\text { Analysis }\end{array}$ & $\begin{array}{c}\text { Motivation/A } \\
\text { utonomy } \\
\text { Instrument }\end{array}$ & IE design \\
\hline $\begin{array}{l}\text { Kaplan and } \\
\text { Assor [13] }\end{array}$ & 2012 & Israel & SPE & $\begin{array}{c}\text { I-Thou / SDT } \\
\text { / ASID }\end{array}$ & $\begin{array}{c}\text { Correlation } \\
\text { /ANCOVA }\end{array}$ & ASDQ & $\begin{array}{r}\text { ASIT } \\
\text { Dialogue }\end{array}$ \\
$\begin{array}{l}\text { Thomas and } \\
\text { Müller [27] }\end{array}$ & 2014 & Austria & ZB & SDT / SEFT & $\begin{array}{c}\text { M-test } \\
\text { MANOVA }\end{array}$ & SRQ-A & $\begin{array}{c}\text { Classroom / } \\
\text { Lab }\end{array}$ \\
$\begin{array}{l}\text { Abraham and } \\
\text { Barker [2] }\end{array}$ & 2014 & Australia & AJEDP & SEMP & SEM & $\begin{array}{c}\text { PMQ } \\
\text { Constructs }\end{array}$ & N/A \\
\hline
\end{tabular}

Note. AJEDP = Australian Journal of Educational \& Developmental Psychology; SPE - Social Psychology of Education; ZB = Zeitschrift für Bildungsforschung; SEMP = Sustained Enrolment Model for Physics; PMQ = Physics Motivation Questionnaire; ASID = Autonomysupporting I-Thou Dialogue; SDT = Self-Determination Theory; ASIT = Autonomy-Supportive I-Thou Dialogue Program; SRQ-A = Academic Self-Regulation Question; ASDQ = Autonomy Supporting Dialogue Questionnaire; SEFT = Stage-environment Fit Theory 
The conceptual focus of the articles prompted their inclusion in the review because they are directly relevant to the subject matter content specific [4], [8] thematic framework and Autonomy Supportive Interventions (ASI) conceptual focus (see Table 3).

Extracted data was coded to prefigured and emergent nodes descriptive of autonomy supportive behaviors. Nodes were also created to code instructional behaviors specific to physics gender gap reduction and developing cognitive function. Included nodes were, applying physics to a broader world view [27], writing exercise mitigation [7], among other emergent autonomy supportive activity. Data was extracted from the studies on motivation and coded to nodes descriptive of gender gap reeducation and mathematics cognitive development. Where constructs of cognitive development were found in ASI manuscripts, data was coded across respective conceptual frameworks.

\subsection{Sources for the review: Selection, data extraction, and coding for cognitive reasoning ability increases in thinking mathematically and applying structure sense}

Articles investigating increased cognitive math function center on operational definitions including sense making, symbol sense, and structure sense (functions operational on, and expressions symbolized on the set $\mathbf{R}$ [17], [23]), [1], [12], [28] (see Table 4). Some articles included construct considerations of motivation, cognitive development, and instructional design. Of particular significance are studies pursuant of increased physics competency through sense making in mathematical expressions [4], [7]. Additional criteria for manuscript inclusion were studies germane to the thematic focus centering on operational definitions consistent with deep structures [4], [8]. The conceptual focus of the articles and cognitive reasoning operational definition of sense making prompted their inclusion in the review.

Table 4. Characteristics of research papers on Sense Making and Thinking Mathematically

\begin{tabular}{|c|c|c|c|c|c|c|}
\hline Author(s) & Year & Locus & Journal & Conceptual Focus & $\begin{array}{c}\text { Method of } \\
\text { Analysis }\end{array}$ & $\begin{array}{l}\text { Mathematical } \\
\text { Sense Making }\end{array}$ \\
\hline Schoenfeld [25] & 1988 & USA & $E P$ & $\begin{array}{c}\text { Cognitive } \\
\text { Development }\end{array}$ & $\begin{array}{c}\text { Qualitative } \\
\text { Bounded Case }\end{array}$ & Sense Making \\
\hline Arcavi [1] & 1994 & Canada & LM & $\begin{array}{c}\text { Cognitive } \\
\text { Development }\end{array}$ & $\begin{array}{c}\text { Qualitative } \\
\text { Grounded } \\
\text { Theory }\end{array}$ & Symbol Sense \\
\hline $\begin{array}{l}\text { Linchevski and } \\
\text { Livneh [17] }\end{array}$ & 1999 & Canada Israel & ESM & $\begin{array}{c}\text { Cognitive } \\
\text { Development }\end{array}$ & $\begin{array}{c}\text { Mixed } \\
\text { Descriptive } \\
\text { Statistics }\end{array}$ & Structure Sense \\
\hline $\begin{array}{l}\text { Hoch and } \\
\text { Dreyfus [12] }\end{array}$ & 2004 & Israel & $P M E$ & $\begin{array}{c}\text { Cognitive } \\
\text { Development }\end{array}$ & $\begin{array}{c}\text { Mixed } \\
\text { Descriptive } \\
\text { Statistics }\end{array}$ & Structure Sense \\
\hline $\begin{array}{l}\text { Novotna and } \\
\text { Hoch [23] }\end{array}$ & 2008 & $\begin{array}{c}\text { Czech } \\
\text { Republic } \\
\text { Israel }\end{array}$ & MERJ & $\begin{array}{c}\text { Cognitive } \\
\text { Development }\end{array}$ & $\begin{array}{c}\text { Theoretical } \\
\text { Hypotheses } \\
\text { Testing }\end{array}$ & Structure Sense \\
\hline $\begin{array}{l}\text { Baumert, et al. } \\
\text { [4] }\end{array}$ & 2010 & $\begin{array}{l}\text { United States / } \\
\text { Europe }\end{array}$ & $A E R J$ & $\begin{array}{c}\text { Cognitive } \\
\text { Development }\end{array}$ & SEM & Sense Making \\
\hline $\begin{array}{l}\text { Van Stiphout, } \\
\text { Drijvers, and } \\
\text { Gravemeijer } \\
{[28]}\end{array}$ & 2013 & Netherlands & IEJME & $\begin{array}{c}\text { Cognitive } \\
\text { Development }\end{array}$ & Correlation & $\begin{array}{l}\text { Symbol Sense } \\
\text { Structure Sense }\end{array}$ \\
\hline
\end{tabular}

Note. $\mathrm{LM}=$ For the Learning of Mathematics; PME = Proceedings of the 28th Conference of the International Group for the Psychology of Mathematics Education; ESM = Educational Studies in Mathematics; MERJ = Mathematics Education Research Journal; EP = Educational Psychologist; IEJME = International Electronic Journal of Mathematics Education; AERJ = American Educational Research Journal 
Data extraction and coding centered on pedagogical techniques addressing cognitive development in sense making and thinking mathematically. The seven research articles identified were coded to nodes conventionally characteristic of mathematical vector spaces [16]. Vector spaces are natural generalizations of a Euclidian Space (Newtonian physics course content space). Nodes were prefigured to mathematical conceptual descriptors; (a) mathematical functions, (b) the real number set $\mathbf{R}$, and (c) and a metric (usual distance on $\mathbf{R}$ ). Emergent nodes were coded to the sense making operational definitions: symbol sense, structure sense, and thinking mathematically.

Additionally, data was extracted from mathematics cognition studies and coded to nodes descriptive of motivational controls and constructs pertinent to increased physics leaning outcomes.
Where motivational controls were found in mathematics cognition studies, data was coded according to constructs of the dialectic conceptual framework [13], [24].

\section{Data evaluation and analysis}

Data analysis for this review sought to synthesize current literature in cross-disciplinary subject research. A thematic focus was provided encompassing the goal. A rubric assisted the researcher in evaluating selected articles according to the review's thematic focus. Three levels of each conceptual focus are formulated according to conventional elements of research design, and assigned to manuscripts (see Figure 1 and Table 5).

\begin{tabular}{|c|c|c|c|}
\hline \multirow{2}{*}{ Criteria/Level } & \multicolumn{3}{|c|}{ Conceptual Focus Level } \\
\hline & High -2 & Medium - 1 & Low - 0 \\
\hline $\begin{array}{l}\text { Concept Inventory (CI) } \\
\text { Instrument }\end{array}$ & $\begin{array}{l}\text { CI instrument is an element } \\
\text { of research purpose; the } \\
\text { conceptual framework; the } \\
\text { methodology procedure, data } \\
\text { analysis, and findings; and } \\
\text { limitations or implications of } \\
\text { research paper }\end{array}$ & $\begin{array}{l}\text { CI instrument is an } \\
\text { element of research } \\
\text { purpose; the framework; } \\
\text { OR the methodology } \\
\text { procedure, data analysis, } \\
\text { and findings OR the } \\
\text { limitations of research } \\
\text { paper }\end{array}$ & $\begin{array}{l}\text { CI instrument is an element } \\
\text { of ONLY the limitations or } \\
\text { implications of research } \\
\text { paper OR not considered at } \\
\text { all }\end{array}$ \\
\hline IE design & $\begin{array}{l}\text { IE design is an element of } \\
\text { research purpose; the } \\
\text { conceptual framework; the } \\
\text { methodology procedure, data } \\
\text { analysis, and findings; and } \\
\text { limitations or implications of } \\
\text { research paper }\end{array}$ & $\begin{array}{l}\text { IE design is an element of } \\
\text { research purpose; the } \\
\text { framework; OR the } \\
\text { methodology procedure, } \\
\text { data analysis, and } \\
\text { findings OR the } \\
\text { limitations of research } \\
\text { paper }\end{array}$ & $\begin{array}{l}\text { IE design is an element of } \\
\text { ONLY the limitations or } \\
\text { implications of research } \\
\text { paper OR not considered at } \\
\text { all }\end{array}$ \\
\hline $\begin{array}{l}\text { Motivation/ Autonomy } \\
\text { Support }\end{array}$ & $\begin{array}{l}\text { Motivation /Autonomy } \\
\text { Support is an element of } \\
\text { research purpose; the } \\
\text { conceptual framework; the } \\
\text { methodology procedure, data } \\
\text { analysis, and findings; and } \\
\text { limitations or implications of } \\
\text { research paper }\end{array}$ & $\begin{array}{l}\text { Motivation /Autonomy } \\
\text { Support is an element of } \\
\text { research purpose; the } \\
\text { framework OR the } \\
\text { methodology procedure, } \\
\text { data analysis, and } \\
\text { findings OR the } \\
\text { limitations of research } \\
\text { paper }\end{array}$ & $\begin{array}{l}\text { Motivation/Autonomy } \\
\text { Support is an element of } \\
\text { ONLY the limitations or } \\
\text { implications of research } \\
\text { paper OR not considered at } \\
\text { all }\end{array}$ \\
\hline $\begin{array}{l}\text { Thinking Mathematically/ } \\
\text { Reasoning/Sense Making } \\
\text { Focus }\end{array}$ & $\begin{array}{l}\text { Thinking Mathematically / } \\
\text { Reasoning/ Sense Making is } \\
\text { an element of research } \\
\text { purpose; the conceptual } \\
\text { framework; the methodology } \\
\text { procedure, data analysis, and } \\
\text { findings; and limitations or } \\
\text { implications of research } \\
\text { paper }\end{array}$ & $\begin{array}{l}\text { Thinking Mathematically } \\
\text { / Reasoning/ Sense } \\
\text { Making is an element of } \\
\text { research purpose; the } \\
\text { framework; OR the } \\
\text { methodology procedure, } \\
\text { data analysis, and } \\
\text { findings OR the } \\
\text { limitations of research } \\
\text { paper }\end{array}$ & $\begin{array}{l}\text { Thinking Mathematically / } \\
\text { Reasoning/ Sense Making is } \\
\text { an element of ONLY the } \\
\text { limitations or implications of } \\
\text { research paper OR not } \\
\text { considered at all }\end{array}$ \\
\hline
\end{tabular}

Figure 1. Rubric for article relevance to the review's thematic framework 
The conceptual focus level rubric assisted the author of the review in getting a broad perspective of contributions of articles utilized in the review. Each article was scored with a summative value from zero to eight, with the higher value reflecting greater contribution to the thematic focus of the systematic review (see Table 5).

Table 5. Article score according to the review's thematic focus and respective conceptual foci

\begin{tabular}{|c|c|c|c|c|c|c|}
\hline \multirow[b]{4}{*}{ Author(s) } & \multirow[b]{4}{*}{ Year } & \multicolumn{4}{|c|}{ Criterion of Thematic Focus } & \multirow[t]{4}{*}{ Score } \\
\hline & & \multicolumn{3}{|c|}{ Gender Gap Reeducation Focus } & \multirow{2}{*}{$\begin{array}{c}\text { Cognitive Development } \\
\text { Focus }\end{array}$} & \\
\hline & & Instrument & Instruction & ing Focus & & \\
\hline & & $\begin{array}{l}\text { Physics / } \\
\text { Math } \\
\text { Concept } \\
\text { Inventory }\end{array}$ & $\begin{array}{c}\text { Motivation / } \\
\text { Autonomy } \\
\text { Support }\end{array}$ & IE design & $\begin{array}{l}\text { Thinking Mathematically/ } \\
\text { Reasoning/ Sense Making }\end{array}$ & \\
\hline Schoenfeld [25] & 1988 & 0 & 0 & 0 & 2 & 2 \\
\hline Arcavi [1] & 1994 & 0 & 0 & 0 & 2 & 2 \\
\hline $\begin{array}{l}\text { Linchevski and } \\
\text { Livneh [17] }\end{array}$ & 1999 & 0 & 0 & 0 & 2 & 2 \\
\hline $\begin{array}{l}\text { Hoch and } \\
\text { Dreyfus [12] }\end{array}$ & 2004 & 0 & 0 & 0 & 2 & 2 \\
\hline $\begin{array}{l}\text { Coletta and } \\
\text { Phillips [5] }\end{array}$ & 2005 & 2 & 1 & 2 & 2 & 7 \\
\hline $\begin{array}{l}\text { Lorenzo, } \\
\text { Crouch, and } \\
\text { Mazur [18] }\end{array}$ & 2006 & 2 & 1 & 2 & 1 & 6 \\
\hline $\begin{array}{l}\text { Novotna and } \\
\text { Hoch [23] }\end{array}$ & 2008 & 0 & 0 & 0 & 2 & 2 \\
\hline $\begin{array}{l}\text { Kost, Pollock, } \\
\text { and Finkelstein } \\
{[15]}\end{array}$ & 2009 & 2 & 0 & 2 & 2 & 6 \\
\hline $\begin{array}{l}\text { Baumert, et al. } \\
\text { [4] }\end{array}$ & 2010 & 2 & 2 & 1 & 2 & 7 \\
\hline Hazari et al.[11] & 2013 & 2 & 2 & 0 & 2 & 6 \\
\hline Adegoke [3] & 2012 & 2 & 1 & 2 & 0 & 5 \\
\hline $\begin{array}{l}\text { Coletta, } \\
\text { Phillips, and } \\
\text { Steinert [7] }\end{array}$ & 2012 & 2 & 0 & 2 & 2 & 6 \\
\hline $\begin{array}{l}\text { Kaplan and } \\
\text { Assor [13] }\end{array}$ & 2012 & 0 & 2 & 2 & 1 & 5 \\
\hline $\begin{array}{l}\text { Van Stiphout, } \\
\text { Drijvers, and } \\
\text { Gravemeijer } \\
{[28]}\end{array}$ & 2013 & 2 & 0 & 2 & 2 & 6 \\
\hline $\begin{array}{l}\text { Abraham and } \\
\text { Barker [2] }\end{array}$ & 2014 & 1 & 2 & 1 & 0 & 4 \\
\hline $\begin{array}{l}\text { Thomas and } \\
\text { Müller [27] }\end{array}$ & 2014 & 1 & 2 & 1 & 0 & 4 \\
\hline $\begin{array}{l}\text { Shi, He, Wang, } \\
\text { and Huan [26] }\end{array}$ & 2015 & 1 & 1 & 0 & 0 & 2 \\
\hline
\end{tabular}

\section{Article synthesis and analysis}

Before discussing specific findings, limitations, and implications of the review, it is beneficial to justify this timely review in light of the rubric evaluations. As stated earlier, this review is to inform research specific to physics and mathematics learning. The pioneering investigations utilized in this review have made it possible. The author commends the authors of these studies for their significant contribution toward empirical knowledge building in physics and mathematics learning. Although the rubric evaluation finds that only seven of seventeen rigorously selected articles scored above five in supporting the thematic focus; the scoring proportions help exemplify the significance of this review. Of the eleven articles scoring high in reasoning ability cognitive development 
investigation design; only two included significant gender gap considerations for autonomy support, concept inventory measurement, and IE design utilization [4], [5]. Of the eight articles scoring high on utilizing concept inventory instrumentation, six manuscripts included mathematics conceptualization considerations. Of the six scoring high in the evaluation of both physics and mathematics conceptualizations; four scored low or excluded autonomy support behavior analysis. This review supports a need for future investigations to simultaneously investigate relationships among all three conceptual foci stated at the onset of this investigation.

The survey of research methodologies displayed in tables of this review is informative of the nature of physics and mathematics learning research. Analysis of nodes coded from the manuscripts support a continued use of the thematic focus used in this review, and may be a consideration for future investigations (see Table 1 and Figure 2) [4], [5], [7], [11].

\section{Discussion of findings, limitations, and implications}

This timely review is the first of its kind with an objective to examine the extent of physics learning studies with concurrent considerations of intrinsic motivation, mathematics cognitive development, and gender gap performance reduction. Carefully selected articles best fitting the reviews framework do not individually incorporate fully cross-curricular learning considerations. Even under this limitation, the review does have specific recommendations beneficial to educators seeking to meet inclusive education goals.

Specific teaching methods are required for proper vertical and horizontal integration of science and mathematics subject matter content [8]. Instruction void of subject specific instructional methods focus on surface structure processing rather than deep learning cognition development [8], [25]. Expert instructors design instructional episodes within complex social and cultural settings to maximize students' potential for extensive ID2 phase integration of new knowledge into students' current subject specific domain knowledge bases. Particular physics and mathematics pedagogical interventions may need to be formatively instituted to insure that surface structure processing, typical of experimental learning psychology, support rather than impede outcome based deep learning cognition development. Specific Newtonian domain knowledge elements requiring vertical and horizontal integration, are items subject to open system mini-experts customizing ID phases to deliver instructional transactions conducive to structure sense conceptualization [8], [17], [19]. This review's summative evaluation finds inclusive education improvement in physics learning, dependent on supporting development in thinking mathematically, may be significantly impacted by concurrent pedagogical considerations for IE learning environments, structure sense conceptualization, and subject specific instructional transactions [9].

Subject specific instructional design dominantly implementing procedural learning can result in a lack of conceptual structure development and an inability to use mathematics and science in a meaningful way [23]. Well planned, direct teacher intervention is necessary for subject specific cognitive development [4], [17]. Curricula and technology tools do not embody knowledge representations as a closed system sufficient for learner mental modeling of hidden structures in complex mathematical and physics content [1], [19], [23]. Instructor pedagogical content knowledge (PCK), as a component of cognitive activation processes in the classroom; is directly integral to quality instructional ID2 transactions, while promoting student voluntary exposure to challenging tasks in conceptual model development [4], [27].

\section{Conclusions}

This review exemplifies the need for further studies in physics learning to be inclusive of considerations for reasoning ability; specifically, skills in representing and explaining structure sense within the mathematical construct of a Euclidian Space [5], [6], [16], [17], [23] (see Figure 2.). Researchers may need to explore mini-experts' role in ID2 hierarchical knowledge representations: physics/math cognitive development $\rightarrow$ thinking mathematically / thinking in physics $(T I P) \rightarrow$ sense making $\rightarrow$ structure sense / symbol sense $\rightarrow$ metric sense [7] (see Figure 3.). Metric sense constructs are the cognitive science instructional representations of variables in symbols conveyed in transactions between instructors and students in complex cultural environments. Node coding relationships found in this review strongly suggest researchers concurrently explore sense making ID2 knowledge representations [14], [19] in physics learning [6], [7], mathematics learning [1], [12], [17], physics/math instruction [4], [8], and autonomy supportive intervention (e. g. learning gap reduction intervention) [4], [8], [11], [20] (see Figure 2). 


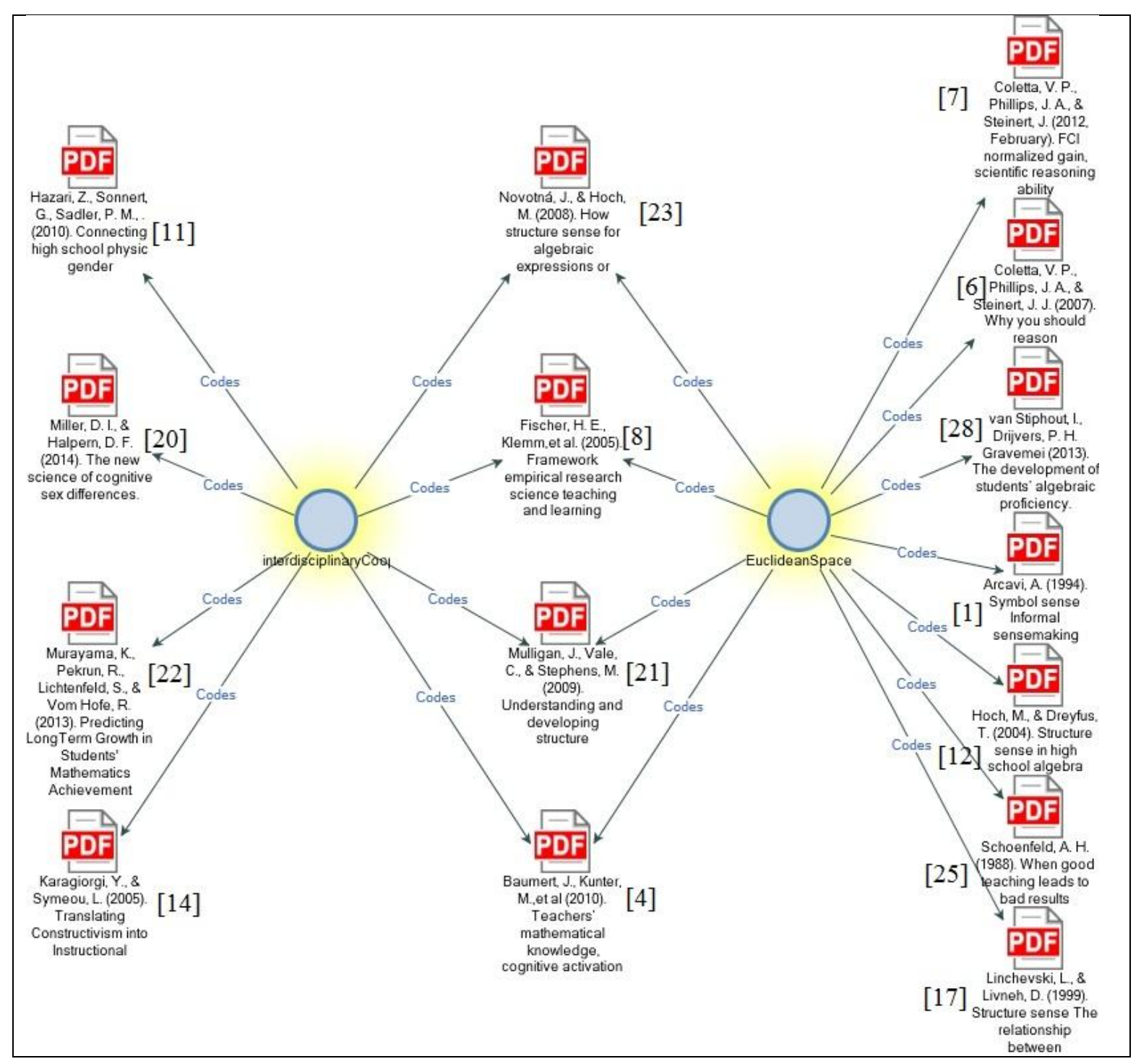

Figure 2. Manuscript sources for Euclidian Space and thematic focus nodes

Inclusion of structure sense in behaviorist studies is consistent with second generation instructional design, approaching a moderation of constructivism [8], [14]. As a result of the guiding question, it is found that measuring the mathematics learning construct of metric sense may be significant in researching physics instruction and meeting inclusive education goals [28]. This systematic review of selected literature illustrates a need for research concurrently investigating (a) autonomy-supportive behaviors specific to physics (b) instructional behaviors toward increased mathematics reasoning skills (e.g. thinking mathematically, sense making, structure sense, metric sense), and (c) subject specific pedagogical behaviors consistent with second generation instructional design (see Figure 2). Conceptual models including content specific instructional design for increased learner performance in physics or mathematics may need to be refined to include constructs for capturing structure sense. 


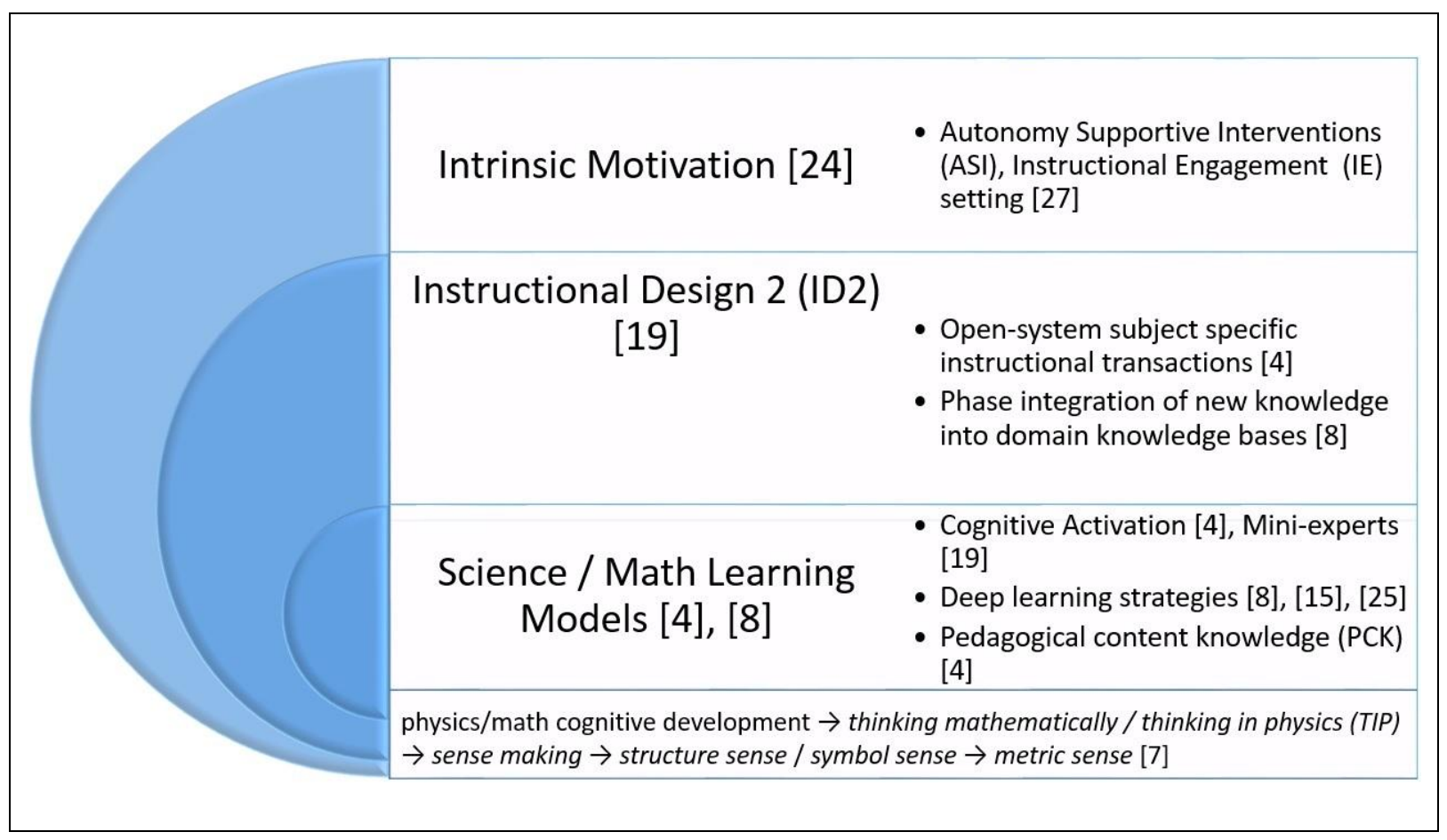

Figure 3. Future research: Hypotheses of relationships for metric sense and physics learning

Supervisors of physics instructors need to have differentiated assessment instruments to negotiate responsibilities in clinical observation collaborative conferences. Educator consortiums have facilitated the development of new assessment instruments designed to interpret instructional episodes. This review is timely in regards to integrating empirical evidence for supporting subject specific instructional practices toward inclusive education school goals.

\section{References}

[1] Arcavi, A. (1994). Symbol sense: Informal sensemaking in formal mathematics. For the learning of Mathematics, 14(3), 24-35.

[2] Abraham, J., \& Barker, K. (2014). Sustaining young people's enrolment intentions in relation to physics: Development and validation of a tool. The Australian Journal of Educational \& Developmental Psychology, 14, 93-116.

[3] Adegoke, B. A. (2012). Impact of interactive engagement on reducing the gender gap in quantum physics learning outcomes among senior secondary school students. Physics Education, 47(4), 462.

[4] Baumert, J., Kunter, M., Blum, W., Brunner, M., Voss, T., Jordan, A., Klosmann, U., Krauss, S., Neubrand, M., \& Tsai, Y. M. (2010). Teachers' mathematical knowledge, cognitive activation in the classroom, and student progress. American Educational Research Journal, 47(1), 133-180.

[5] Coletta, V. P., \& Phillips, J. A. (2005). Interpreting FCI scores: Normalized gain, preinstruction scores, and scientific reasoning ability. American Journal of Physics, 73(12), 1172-1182.

[6] Coletta, V. P., Phillips, J. A., \& Steinert, J. J. (2007). Why you should measure your students' reasoning ability. The Physics Teacher, 45(4), 235-238

[7] Coletta, V. P., Phillips, J. A., \& Steinert, J. (2012). FCI normalized gain, scientific reasoning ability, thinking in physics, and gender effects. American Institute of Physics Conference Series, 1413, 23-26.

[8] Fischer, H. E., Klemm, K., Leutner, D., Sumfleth, E., Tiemann, R., \& Wirth, J. (2005). Framework for empirical research on science teaching and learning. Journal of Science Teacher Education, 16(4), 309-349.

[9] Gough, D., Thomas, J., \& Oliver, S. (2012). Clarifying differences between review designs and methods. Systematic Reviews, 1(1), 1-9.

[10] Hausmann, R., Tyson, L. D., \& Zahidi, S. (2007). The global gender gap report 2007. Switzerland: World Economic Forum.

[11] Hazari, Z., Sadler, P. M., \& Sonnert, G. (2013). Research and Teaching. The Science Identity of College Students: Exploring the Intersection of Gender, Race, 
and Ethnicity. Journal of College Science Teaching, 42(5), 82-91.

[12] Hoch, M., \& Dreyfus, T. (2004). Structure sense in high school algebra: The effect of brackets. In Proceedings of the 28th Conference of the International Group for the Psychology of Mathematics Education, 3, 49-56.

[13] Kaplan, H., \& Assor, A. (2012). Enhancing autonomy-supportive I-Thou dialogue in schools: conceptualization and socio-emotional effects of an intervention program. Social psychology of education, 15(2), 251-269.

[14] Karagiorgi, Y., \& Symeou, L. (2005). Translating Constructivism into Instructional Design: Potential and Limitations. Educational Technology \& Society, 8 (1), 17-27.

[15] Kost, L. E., Pollock, S. J., \& Finkelstein, N. D. (2009). Characterizing the gender gap in introductory physics. Physical Review Special Topics-Physics Education Research, 5(1), 010101.

[16] Lear, J. C. (1993). Barrelled spaces (Order No. EP21603). Available from ProQuest Dissertations \& Theses Full Text; ProQuest Dissertations \& Theses Global. (304084654). Retrieved June 2, 2015 from http://search.proquest.com/docview/304084654

[17] Linchevski, L., \& Livneh, D. (1999). Structure sense: The relationship between algebraic and numerical contexts. Educational Studies in Mathematics, 40(2), 173-196.

[18] Lorenzo, M., Crouch, C. H., \& Mazur, E. (2006). Reducing the gender gap in the physics classroom. American Journal of Physics, 74(2), 118-122.

[19] Merrill, M. D., Li, Z., \& Jones, M. K. (1990). Second generation instructional design (ID2). Educational Technology, 30(2), 7-14.

[20] Miller, D. I., \& Halpern, D. F. (2014). The new science of cognitive sex differences. Trends in cognitive sciences, 18(1), 37-45.

[21] Mulligan, J., Vale, C., \& Stephens, M. (2009). Understanding and developing structure-Its importance for mathematics learning. Mathematics education research journal, 21(2), 1-4.

[22] Murayama, K., Pekrun, R., Lichtenfeld, S., \& Vom Hofe, R. (2013). Predicting Long-Term Growth in Students' Mathematics Achievement: The Unique Contributions of Motivation and Cognitive Strategies. Child development, 84(4), 1475-1490.

[23] Novotná, J., \& Hoch, M. (2008). How structure sense for algebraic expressions or equations is related to structure sense for abstract algebra. Mathematics Education Research Journal, 20(2), 93-104.
[24] Ryan, R. M., \& Deci, E. L. (2000). Intrinsic and extrinsic motivations: Classic definitions and new directions. Contemporary educational psychology, 25(1), 54-67

[25] Schoenfeld, A. H. (1988). When good teaching leads to bad results: The disasters of' 'well-taught' mathematics courses. Educational psychologist, 23(2), $145-166$.

[26] Shi, W. Z., He, X., Wang, Y., \& Huan, W. (2015). Effects of Lab Group Sex Composition on Physics Learning. Eurasia Journal of Mathematics, Science \& Technology Education, 11(1), 87-92.

[27] Thomas, M. A. E., \& Müller, F. H. (2014). Autonomy support: a key for understanding students learning motivation in science?. Zeitschrift für Bildungsforschung, 4(1), 43-61.

[28] Van Stiphout, I., Drijvers, P. H. M., \& Gravemeijer, K. P. E. (2013). The development of students' algebraic proficiency. International Electronic Journal of Mathematics Education, 8(2-3), 62-80. 